\title{
The adaptation process in port governance: the case of the Latin countries in South America and Europe
}

\author{
Fernando González Laxe ${ }^{1}$, Ricardo J. Sánchez ${ }^{2}$ and Lorena Garcia-Alonso ${ }^{3^{*}}$ (D)
}

\author{
*Correspondence: lorena@uniovi.es \\ ${ }^{3}$ Regional Economics Laboratory \\ (REGIOlab). Applied Economics \\ Department, University of Oviedo, \\ Oviedo, Spain \\ Full list of author information is \\ available at the end of the article
}

\begin{abstract}
The particular location of port infrastructure holds characteristics that determine the activity of the port, both with respect to traffic and with respect to implementing competitive strategies; and the efficiency and efficacy of infrastructure depend on the governance systems that regulate the ports. Likewise, the development of port activity echoes in the regional economy as well, hence governance becomes integral to maximizing the impact of ports on their region's economic development. However, the activity of a port transcends the domestic/regional frontiers, as long as the port intends to take part in a global supply chain. Achieving this aim poses a challenge on the authorities that govern port activity, and this challenge needs to be seized when it comes to adjusting the governance to external and internal goals. In the specific case of the analysed ports, the prevailing governance model is known as Landlord, which differs noticeably from port to port. These differences make it possible to distinguish the orientation of European ports from that of the analysed Latin American ports, showing a dissimilar adjustment of the conception of governance that followed objectives that were not simultaneous. The paper draws forth a questioning of the uniqueness of the denomination Landlord and its legitimacy given the new challenges. Furthermore, the paper opens the way to understanding the need to adapt governance to changes, given the examined experiences. The analysis covers the following cases: Argentina, Brazil, Chile, Colombia, France, Italy, Portugal and Spain.
\end{abstract}

Keywords: Governance, Port system, Ports, Latin America, Europe

\section{Introduction}

In general terms, a governance model is derived from a sequence of circumstances. Therefore, it is able to evolve on time and to face new challenges by reforming itself. Each reform configures a new governance model, as Fig. 1 shows. Originally crafted by Brooks and Cullinane (2007), the Figure allows to explain many of the changes that took place in European and Latin American ports when a wave of reforms first took place in the 90 s.

At the very beginning, changes on governance model could be related to market changes, the establishment of new goals, the disposal of additional resources, a technological innovation or merely the saturation and inefficiency of the port facilities and services.

(c) The Author(s). 2016 Open Access This article is distributed under the terms of the Creative Commons Attribution 4.0 International License (http://creativecommons.org/licenses/by/4.0/), which permits unrestricted use, distribution, and reproduction in any medium, provided you give appropriate credit to the original author(s) and the source, provide a link to the Creative Commons license, and indicate if changes were made. 


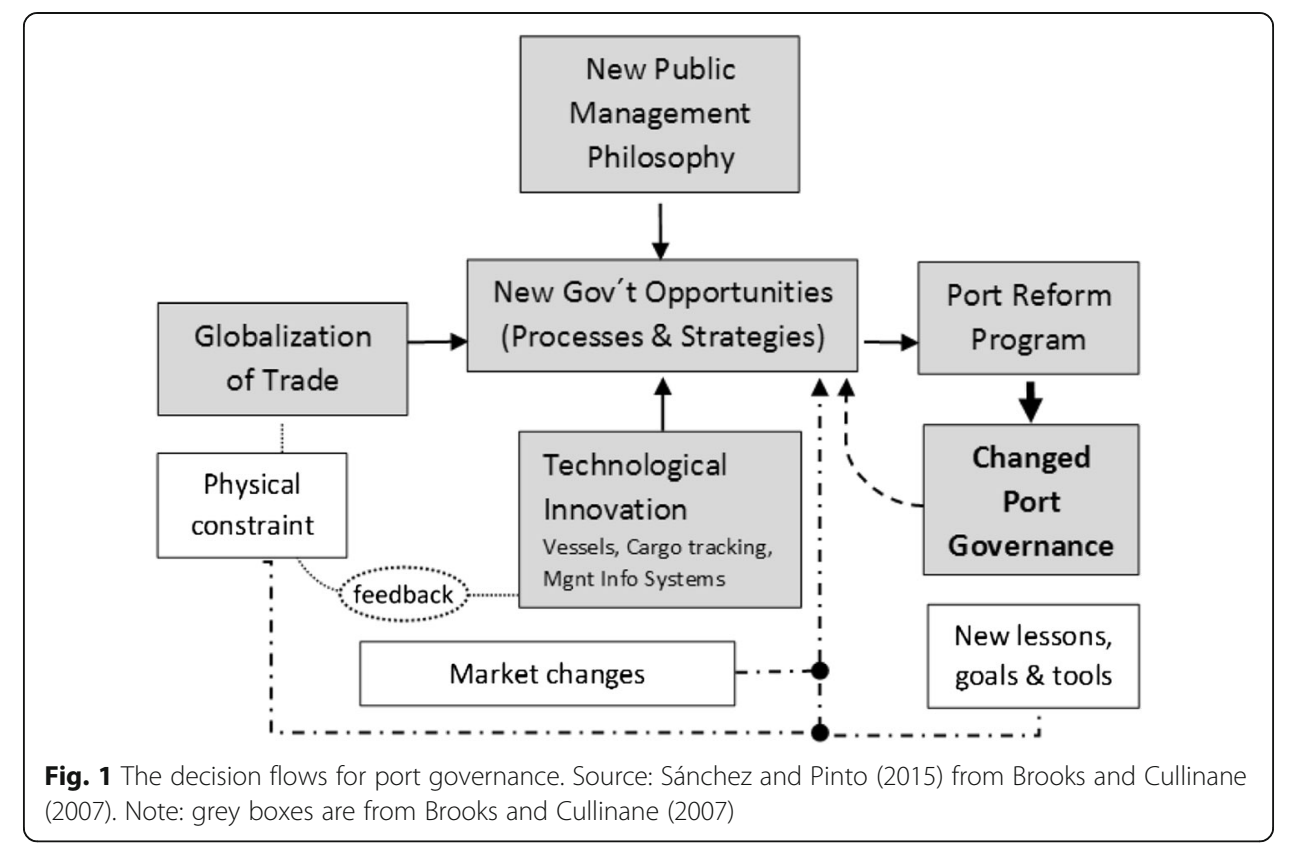

However, over the time, reasons that lead governance reform are being modified, for example: deepen changes happening in the market; traditional ports facing physical restrictions that require the construction of new facilities (greenfield ports); lessons to learn from the reform process and new legal and regulatory instruments appearing; or some objectives from the original reforms are being accomplished and new strategic targets appear. The process to face any of these new challenges is not always simple. This fact could cause the reform to follow an unexpected path or even to never take place.

The aim of this paper is to compare how the changes experienced in port activity have been reflected in the port governance reforms conducted in the Latin countries both in South America and in Europe.

In South America, the chosen cases were Argentina, Brazil, Chile and Colombia. The choice was based on two reasons: 1 . The age of reforms; 2 . The relevance in the total quantity of containers operated in the region. Indeed, the four countries were pioneers in Latin American port reforms (along with Mexico and Uruguay), and provided guidance to other national reforms that occurred later. The 2013-2015 average participation of the four countries on the total throughput of South America was 76\% (CEPAL, 2015). The cases in Southern Europe: France, Italy, Portugal and Spain, correspond to the definition indicated on the paper as countries of "Latin origin" on both continents.

The object of work of this paper is the port governance. However, each port tends to generate new governance structures in accordance with national regulations. Therefore, there is a relationship between port reform and governance (as it is shown in Fig. 1) and, in order to better understand the kind of governance that exists in each case, port reforms must be analysed.

In this paper, the approach to port governance is general, considering the port authority and the cluster as a whole in terms of governance.

To deal with the paper's goal, firstly the governance concept is introduced and analysed from a literature review in "The port governance concept" section, specially 
focused in the port governance issue. The case studies dealing with South American and the European countries are shown in "Cases analysis" section. The analysis applied in this section is mainly qualitative; data collection methods used for this section include literature review, legal documents revision and interviews to both public and private port officials. Finally, "Discussion" and "Conclusions" sections respectively, present the discussion and summarizes the main conclusions drawn as well as introduces the pending points for further research in this field.

\section{The port governance concept}

The governance concept is usually understood as a governmental issue. However, this concept goes beyond the public context, and can also be approached from the corporate and social perspective. According to Stoker (1998) cited in Lam et al. (2013) "governance is a complex set of institutions and actors drawn from, and also beyond, government. It identifies self-governing mechanisms of actors". Similarly, Monios (2015) argues that "official government institutions become only one part of the totality of the governance process. Governance then becomes a broader process of distributing authority and allocating resources, of managing relationships, behaviour or processes to achieve a desired outcome."

From the broader point of view, governance refers to the set of rules and structures available for managing their own strategies; from the administration perspective, governance refers to the set of rules and structures imposed on firms to influence their decisions (Brooks and Cullinane 2007).

In any case, discussing governance means discussing how to provide the proper context for the coordination of the stakeholders involved in an activity in order to maximize their performance as a whole. "Ports are inclined to develop new governance structures, which should be tailored to the specific local conditions in terms of culture and port objectives" (Notteboom 2007, page 438).

According to Geiger (2011), cited in Borges Vieira et al. (2014), any model of governance must take into account three basic queries: who, what and how it governs. These three points are directly related to the cornerstones of the governance: its structure, its actions and its own elements. The structure refers to the regulatory framework; the actions, to the tools leading to coordination; and the elements, to the agents and flows.

Inside the framework of port governance, Talley (2009) highlighted that "Port governance refers to the ownership, management, and control of the operations of a port"; that is, the author presents a perception of the port governance concept similar to that of the World Bank (2007), which indicates what port governance refers to, but does not clarify what it is that it implies. Considering other authors, we can distinguish two levels: the port and the port authority. The first level refers to the socio-economic agents and political bodies linked to a port; the second one, to port management as a firm (Verhoeven and Vanoutrive 2012). In the latter, the governance process is defined according to how the interaction between policy makers and the port authority takes place: the greater the port authority autonomy, the greater its own responsibility in port management performance (Brooks and Pallis 2008). "In seaports, a distinction needs to be made between PA governance and port governance. The governance of the PA is closely linked with corporate governance issues, such as shareholder influence, structure of the board of governors and corporate social responsibility. Port governance, on the 
other hand, is more related to cluster governance since a port consists of a variety of actors" (De Langen 2007, page 458). In the end, the port governance process lies in the establishment of a set of rules compatible with both its trajectory and its future objectives (Brooks 2004). Following González-Laxe (2013), cited in Sanchez and Pinto (2015), the key elements for port governance in practice are the institutions, the mechanisms and the processes involved.

As the guide provided by the World Bank in 2007 (Port Reform Toolkit) states, there are four basic models of port administration, although they can vary according to the legal status of the corresponding port authority (Ferrari et al. 2015). These four models are i) the Service Port, ii) the Tool Port, iii) the Landlord Port and iv) the Private Service Port. They can be distinguished from each other depending on who provides the port services and also who exerts the ownership and the management of the suprainfrastructure: the public or the private sector (for a deeper understanding, see also Brooks (2004), Brooks and Cullinane (2007) or Debrie et al. (2013)). The port model finally chosen depends on the socio-economic context, the location of facilities, the flows of traffic and the historical development (that is, on how the port is organized, structured and managed). The degree of the private sector involvement also depends on the development of the capital market and the country tradition regarding the transport services provision. The governing authority (either at a national, regional or local level) states the legal framework determining the model of port governance. Once the legal framework has been set up, a supervising entity of the port authorities' actions must be established. It can be dependent of either the central government or of minor public administration levels. The configuration of this entity and the degree of autonomy it confers to the port authorities are key in the port governance model definition, making it possible to go beyond the World Bank classification (Sanchez and Pinto 2015).

Brooks and Cullinane (2007) identify five basic alternatives of port governance depending on how the public and the private sectors share the ownership, the management and the control of ports: i) central ownership, management and control; ii) central ownership and local management and control; iii) public ownership and management and control exerted by a corporation; iv) public ownership with private management through a concession arrangement; and finally v) private ownership, management and control. The distribution of both the functions of the ports and their control mechanisms can vary by countries even for the same model. Nevertheless, it is always assumed that the ownership and the assets control lie in the administration when the port model is public, whereas a complete functions transfer from the public sector is required for considering a port model as private.

The conception of port governance models evolves both in time and space because of the confluence of several elements: i) devolution, ii) corporate governance, iii) operational profile, iv) functional autonomy, v) functional pro-activeness, vi) investment responsibility and (vii) financial autonomy (see Verhoeven and Vanoutrive 2012). This evolution has intensified since the 1990s, in line with the devolution programs developed all around the world. Those reforms sought to increase the transparency, optimize the resources and find new financial sources (Brooks 2004) ${ }^{1}$. Additional and relevant changes for the port governance evolution are: i) the new paradigm of ports (nodes instead of places); ii) the need for ports to be competitive, flexible and efficient, iii) the internationalization of cargo handling firms, iv) the confluence of different port 
governance models into the same geographical area and v) a larger spatial scope of ports and a reduction of ties with the cities where they are located (Vanoutrive 2012). It could be concluded that port governance models are influenced by the size of the corresponding port authority (Verhoeven 2011), and evolve because of the socioeconomic framework and the performance of ports (Brooks and Pallis 2008).

Usually, reforms in port governance programmes are imposed by the government looking for an improvement in efficiency, to face budget restrictions or merely for ideological reasons. However, those guidelines do not always lead to the expected result. It is necessary to develop a suitable model of port governance (according to the context and the objectives and challenges stated) in order to achieve the optimal outcome. Despite this, it should be stressed that an entrepreneur context can be more determinant for the port success than any formal model of port governance (when the port authority enjoys a reasonable level of autonomy and the proper legal framework is clearly stated $^{2}$ (Verhoeven 2009). The legitimacy of their acts will be assessed by their outcomes according to their challenges (Vanoutrive 2012).

Indeed, the main objective of port governance is to boost the performance of the facilities through the establishment of a suitable management model ${ }^{3}$. That model must serve to achieve the expected goals (the optimal outcome will never be possible with the wrong model.) Nevertheless, governance is not the only element determining port performance. This is also linked to the efficiency and effectiveness of the port logistics chains (Brooks (2004), Brooks and Pallis (2008), Verhoeven (2011), Borges Vieira et al. (2014). The lack of an active port policy, a poor statement of the goals, the simultaneous development of additional policies with a negative impact on port outcome or merely an inadequate decision could also deliver an unexpected result (Sanchez and Pinto 2015).

Baltazar and Brooks (2001) suggest that port outcome depends on the context. It is known that an inadequate configuration of the port governance model ${ }^{4}$ can lead to troubles in the post-devolution period (Brooks and Pallis 2008). However, despite the relevance of the governance-outcome relationship, there is scarce economic literature going beyond the analysis of the structure and the port functions (Borges Vieira et al. 2014).

In order to fill this gap and deepen the assessment of the governance, Borges Vieira et al. (2014) propose the analysis of port governance by separating its different dimensions. Namely: i) the structure, identifying its components and evaluating its effectiveness and evolution over time; ii) the actions, taking into account the degree of coordination among them at both flows and agents levels; and iii) the elements, through the analysis of the evolution of their coordination degree and the efficiency on the management of flows and information. Their hypothesis is that the port governance model is adequate when it favours the players' integration and increases the efficiency.

The complexity of port governance has increased over time. During the last three decades and independently of the countries' development level, there has been a progressive port devolution process, both through the transference of competences to minor administration levels and through the increase in the participation of the private sector. Likewise, the rules operating in the maritime transport sector are being standardized, services are been homogenized, and economic agents are concentrating on boosting scale and agglomeration economies. Additionally, maritime flows increase introduces 
three new challenges: i) the management of route imbalances and, consequently, the return of empty containers; ii) the congestion of some ports and facilities; and iii) the necessity of a bigger budget to face infrastructure improvements (González Laxe 2008).

Because of all these changes, port activity goes beyond the five basic activities identified by the UNCTAD in 1992. Namely: i) cargo planning; ii) its storage; iii) its receipt and delivery; iv) ship operations; and v) quay operations. As Drewe and Janssen (1996) (among others) highlighted, ports became nodes in logistics chains. That implies new challenges for the port governance. New and more specialised services integrated in complex logistics chains are expected. Following Verhoeven (2009), that means port managers ought to promote: i) a sustainable development of port activity; ii) the port's integration into logistic chains; and iii) the development of market strategies for port management. Vanoutrive (2012) considers that there are basically three challenges to port governance: firstly, he suggests that managers must be able to exert influence on the ports. As the ports shift from places to nodes in logistic chains, it is increasingly difficult to exert that influence because the management of those chains surpasses their competencies. Secondly, there are no citizens in the ports. Therefore, there is a lack of agents upon which to exert influence. Thirdly, the environmental impact of port activity must be taken into account.

The reforms conducted in port governance follow different paths, although the main challenges and objectives of the ports today are very similar all around the world. $\mathrm{Ng}$ and Pallis (2010) drew that conclusion based on the important differences they found among port governance practices conducted in a group of countries. These authors justified those differences because of the observed asymmetries among the countries at the institutional level. Specifically, they found that the role of the ports varies according to the political tradition of each country. In all of the cases, economic agents linked to the maritime sector were included in the management models (although with different degrees of engagement), and a larger financial autonomy was conceded to the ports. However, the new mechanisms can be more closely related to the public administration or to the market depending on the country. The same conclusion can be drawn in the case of the EU. The diversity of rules makes it impossible to identify a European model per se, although the landlord framework is by far the most extended (see Verhoeven (2009) for a revision of the impact of the EU rules on port governance.)

In general terms, it can be concluded that the broadly imposed model assumes the principles of the market economy and realises that the traffic is increasingly concentrated around a small number of ports. Likewise, the devolution processes have changed the balance between the public and the private sector in port management. Nevertheless, changes undergone have not been the same and the models imposed differ among them (Debrie et al. 2013). This paper emphasises these statements by focusing on the Latin countries but grouping them by continent: Europe vs South America.

\section{Cases analysis}

In both Southern Europe and South America, port governance has changed significantly in recent years. Those changes can be examined in two sets: the first is related to external reasons (it intends to answer the question "why should port governance have changed?"), and the second one to the purpose of port reforms (it intends to answer the question "why did port reform take place?"). 
The first set of external reasons, common to the entire analysed block, is linked to the following matters: a) a greater economic globalization of commercial transactions that brought along a substantial shift with respect to the strategic behaviour of the private and public agents participating in the logistics chain; b) a change in the maritime industry that implied a commitment to containers, and to larger and more competitive vessels; as well as a substantial change in the strategies of companies regarding the constitution of new maritime alliances; c) a new port hierarchy stemmed from the appearance of hub ports that shows the new conditions put together by the global economy which impact the maritime and port industries.

The second set ("the actual changes") shows the original reform objectives: a) putting saturated public-sector ports back on a viable footing ${ }^{5}$; b) solving the pre-existing serious problem of port inefficiency; c) reducing fiscal burden coming from ports ${ }^{6}$; d) introducing private-sector capital and business management to create a port services industry that emphasizes market demands and competition. The solution proposed was the application of antimonopoly regimes to ensure that no group within the port community is able to insulate itself from market forces and extract monopoly rents; e) improving external trade competitiveness ${ }^{7}$; f) dealing with the labour problems, low productivity and high costs that existed in almost all ports. This set of changes is mainly, but not exclusively, related to South America cases.

In Latin America, private income was intended to be co-ordinated with a public action different from the previous one. In this sense, "to promote private-sector involvement in port services and port facilities, a central government must adopt a market-oriented institutional framework which reassigns operational, planning and administrative functions among public-sector agencies and private interests, in order to ensure that dominant port groups cannot distort the commercial environment in which trade relations take place" (UNCTAD, 1992). The major elements of such a framework included statutory authority for private participation, deregulation, decentralization, an antimonopoly regime and a public-sector agency that balances competing interests to ensure that no one group can utilize market mechanisms to obtain a monopoly position. The statutory authority should clearly define standards for the approval of private-sector proposals and establish a strong presumption that increased participation will benefit the nation through increased competition, in order to avoid the endless problems and delays of trying to satisfy imprecise regulatory requirements.

In a similar manner, these circumstances stirred the dynamic of a distribution of duties between the public and private sectors among the Southern European countries under analysis thus bringing about a substantial change in port governance.

Where once the model presented a prominent public sector presence (be it of state, regional o local origin); now, port models have become more complex. The private sector is gradually gathering presence in management, while economic, social and institutional agencies have increased participation in decision-making.

An augmented international competition, the consolidation of global supply chains and the increased efficiency and quality of port services demand new immediate responses.

As the investment needed to undertake new initiatives in infrastructure, equipment and facilities fails to be taken on by governments or public authorities, some ports and port institutions face an evident dilemma. In the first place, some ports encounter an 
additional issue in the appearance of certain bottlenecks in logistics chains and in the functioning of port operations that hinder efficient maintenance. Such situations prevent ports from responding to the highly competitive international atmosphere. In certain circumstances, liberalization dynamic starts to take form. Similarly, as functioning ports and their decision-making process fall inside centralizing frameworks, new undertakings are aimed at the start-up of more decentralizing mechanisms, strengthened by new shifts of power among port authorities. Finally, and as a third assumption, the bid is placed on the creation and operation of agencies, entities or corporate organizations, and of privatization dynamics, with the aim of achieving new capabilities of management and liability.

This process can also be approached from the port-devolution perspective (Cullinane and Song (2002), Brooks (2004), Baltazar and Brooks (2007)) of transferring duties from the Administration and central government to other organisms or administrative entities, be them public or private, in order to improve the ability to supervise, develop participation, guarantee management transparency, or incorporate technological advances. As a whole, the content of port-devolution is part of a dynamic applied by certain governments with views on implementing new public management principles in the areas of transport and the maritime-port sector. This means applying new economic and commercial principles to governmental management, favouring stronger liberalization and decentralization processes and answering to the conditions set by the local environment.

\section{Analysis of the mechanisms involved in governance reforms}

In Southern Europe, the reform process gradually adjusted to a new international panorama. Therefore they became governmental responses and, consequently, determinations that lined up with the guidelines of a more competitive, global and open environment, highly integrated in international networks. Meanwhile, in Latin America, reforms followed the trend of a more or less generalised transformation of State involvement in economy at the beginning of the 1990s, after the stimulus of the Washington Consensus. Table 1 exhibits the timeline of the major reforms:

In order to carry out the analysis of governance evolution, a set of analytic categories must be pinpointed. The authors have selected the previously identified cornerstones: structure, actions and elements (where structure refers to the regulatory framework; actions to the tools leading to coordination; and elements, to the agents and flows.) It is also essential to differentiate between the port and the port authority (socio-economic agents and the political bodies and port management.) In summary, the analysis examines the key elements for port governance in practice: the institutions, the mechanisms and the processes. Tables 2 and 3 constitute the main features of the changes in port governance that took place in both regions, following the Vanoutrive (2012) model, coherent with analysed works (Brooks and Cullinane (2007), Verhoeven and Vanoutrive (2012), Brooks (2004), González-Laxe (2013) and Sanchez and Pinto (2015).

\section{Discussion}

The sequences and categories of reform dynamics respond to scales that differ regarding i) private participation; ii) various levels of decentralization; iii) unequal advantages 
Table 1 Timeline of port reforms

\begin{tabular}{|c|c|c|c|c|c|c|c|c|}
\hline & Argentina & Brazil & Chile & Colombia & France & Italy & Portugal & Spain \\
\hline 1991 & & & & Col-91 & & & & \\
\hline 1992 & & & & & & & & Spa-92 \\
\hline 1993 & Arg-93 & Bra-93 & & & & & & \\
\hline 1994 & & & & & & Ita-94 & & \\
\hline 1997 & Arg-97 & & Chi-97 & & & & & \\
\hline 1998 & & & & & & & Por-98 & \\
\hline \multicolumn{9}{|l|}{ - - } \\
\hline 2001 & & Bra-01 & & & & & & \\
\hline 2002 & & & & & & & Por-02 & \\
\hline 2003 & & & & & & & & Spa-03 \\
\hline 2004 & & & & & Fra-04 & & & \\
\hline 2005 & & & Chi-05 & & & & & \\
\hline \multicolumn{9}{|l|}{2006} \\
\hline 2007 & & Bra-07 & & & & & Por-07 & \\
\hline 2008 & & Bra-08 & & & Fra-08 & & & \\
\hline \multicolumn{9}{|l|}{2009} \\
\hline 2010 & & & & & & & & Spa-10 \\
\hline 2011 & & & & & & & & Spa-11 \\
\hline 2012 & Arg-12 & & & & & & Por-12 & \\
\hline 2013 & Arg-13 & Bra-13 & & & & & & \\
\hline 2014 & Arg-14 & & & & & Ita-14 & Por-14 & \\
\hline \multicolumn{9}{|l|}{2015} \\
\hline 2016 & Arg-16 & & & & & Ita-16 & & \\
\hline
\end{tabular}

Source: own development, based on each country's national legislation

in the field of marketing and fees configuration; iv) diverse structures of corporatization; v) dissimilar elements taken in order to compose the governance model and vi) different mechanisms of contracts and duration of concession periods.

The several responses of the port systems in the "Latin countries" of Southern Europe and South America bid on the landlord model, where port administration assumes regulatory functions and controls the port supply, granting concessions on port operation and workforce to the private sector, shaping governance schemes in accordance with the Landlord model.

The first approach to the contents of Tables 2 and 3 has allowed for the formation of new questions about the meaning of governance and the landlord model. The definition of governance is insufficient, especially within the port environment. In this context, various schemes lead to different levels, such as the port, the port authorities or the logistics chain. The central role of the ports calls for a unified governance that will lead the way for synergies and new modes of authority enforcement and resolution of controversies.

Figure 1 shows a variation of the reasons that generate a change in the reforms. The grey sections are those originally studied by Brooks and Cullinane (2007). Afterwards, Sanchez and Pinto (2015) identified additional reasons that call for a change in the 


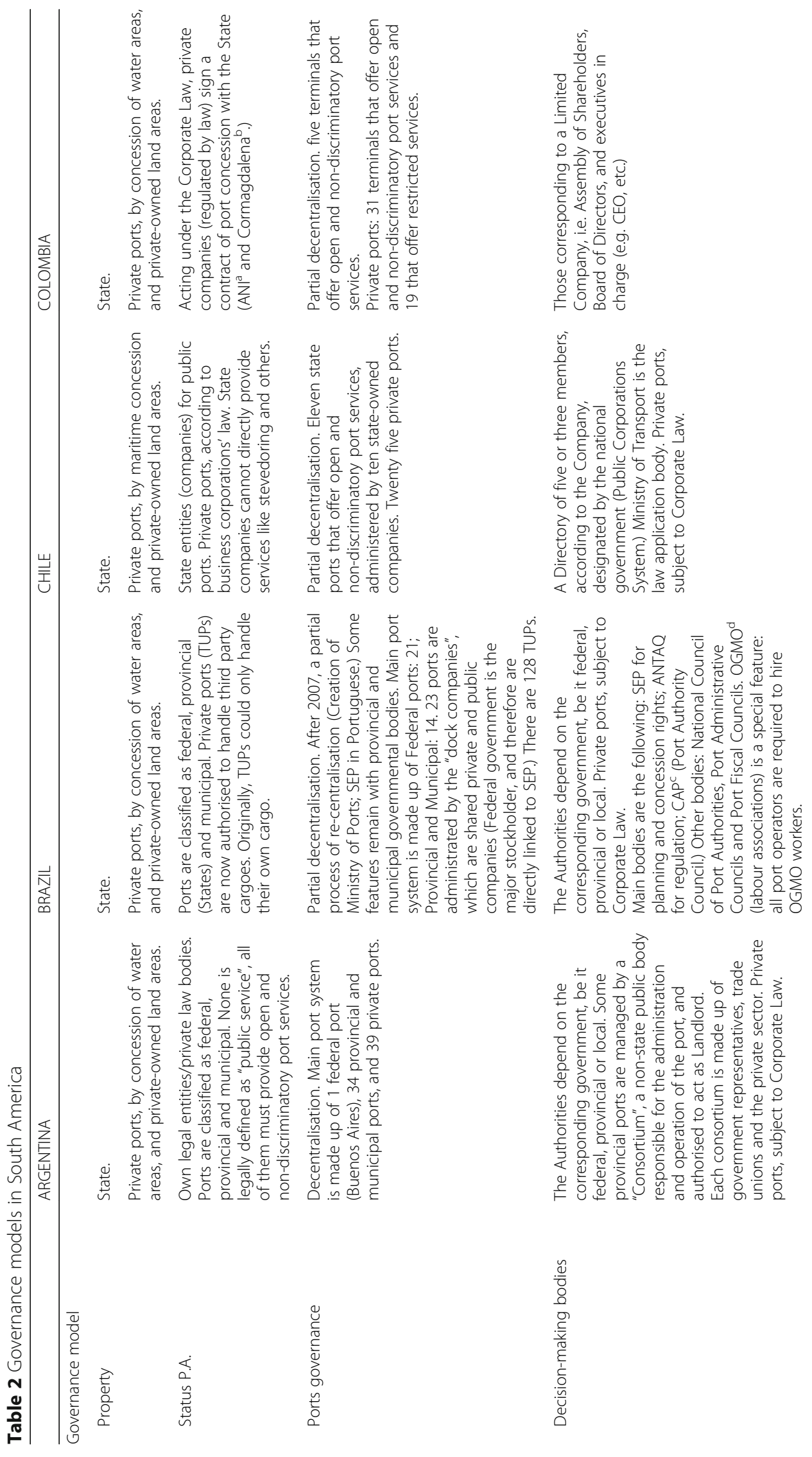




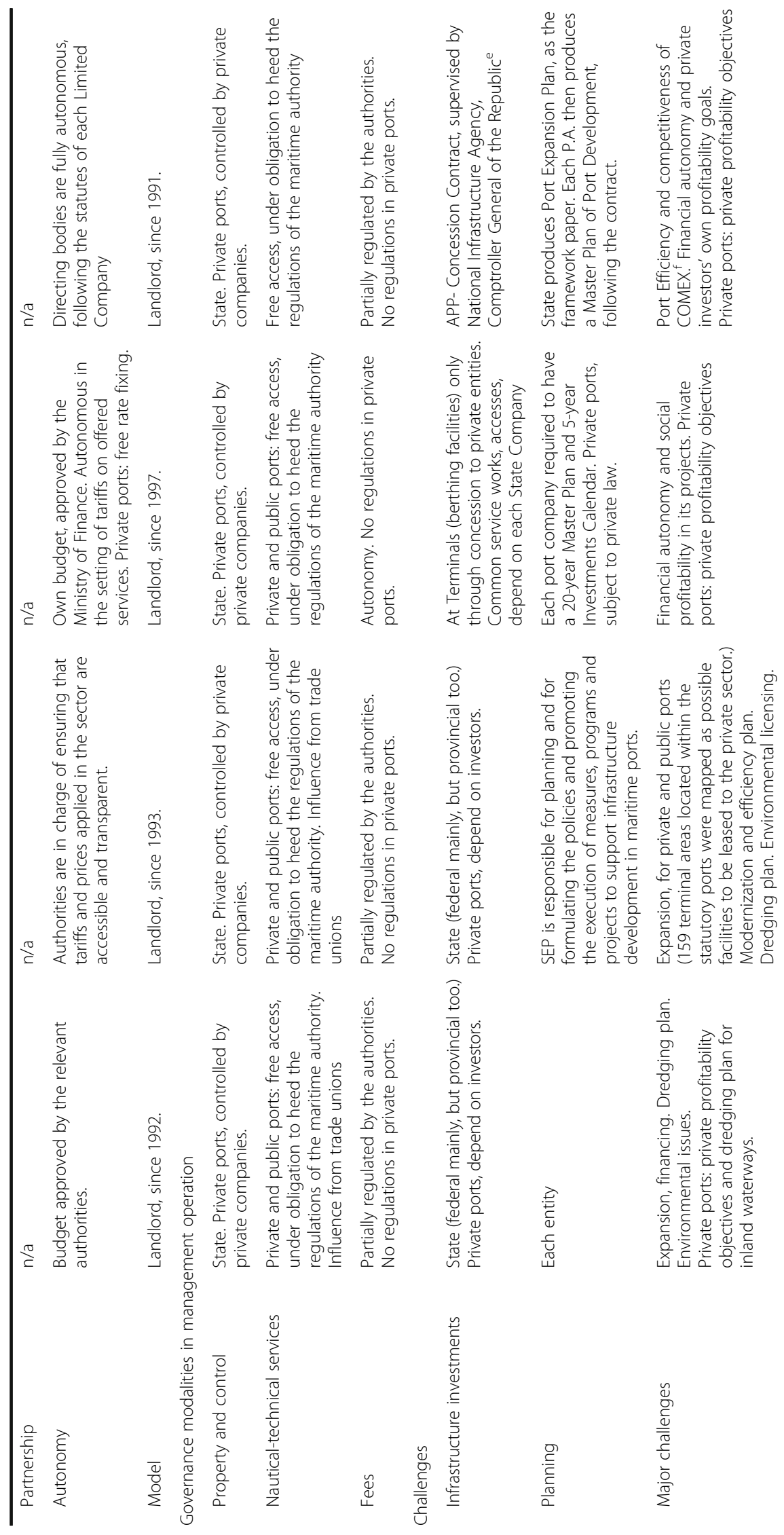




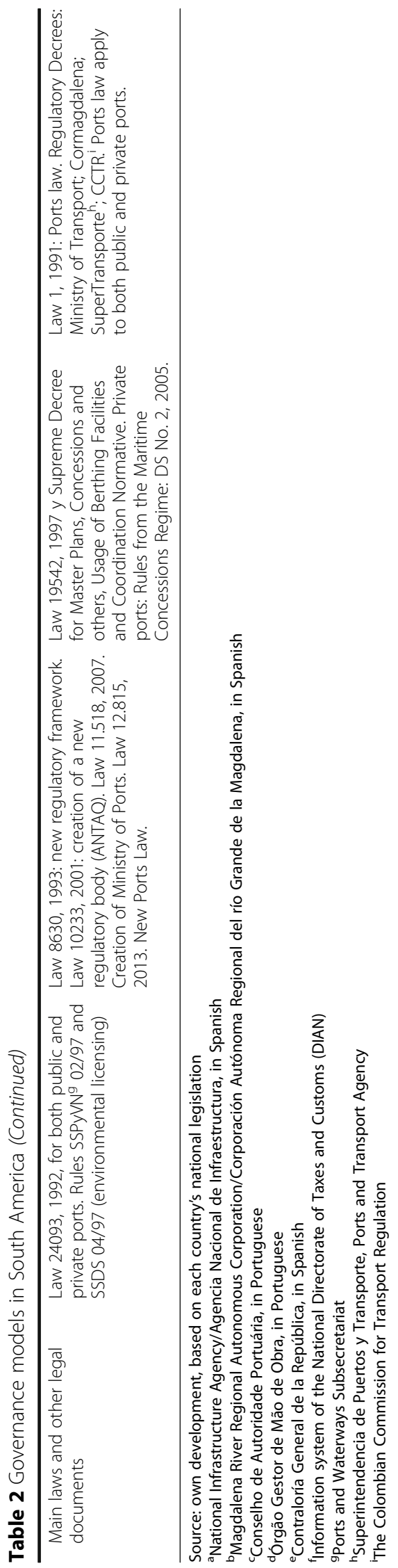




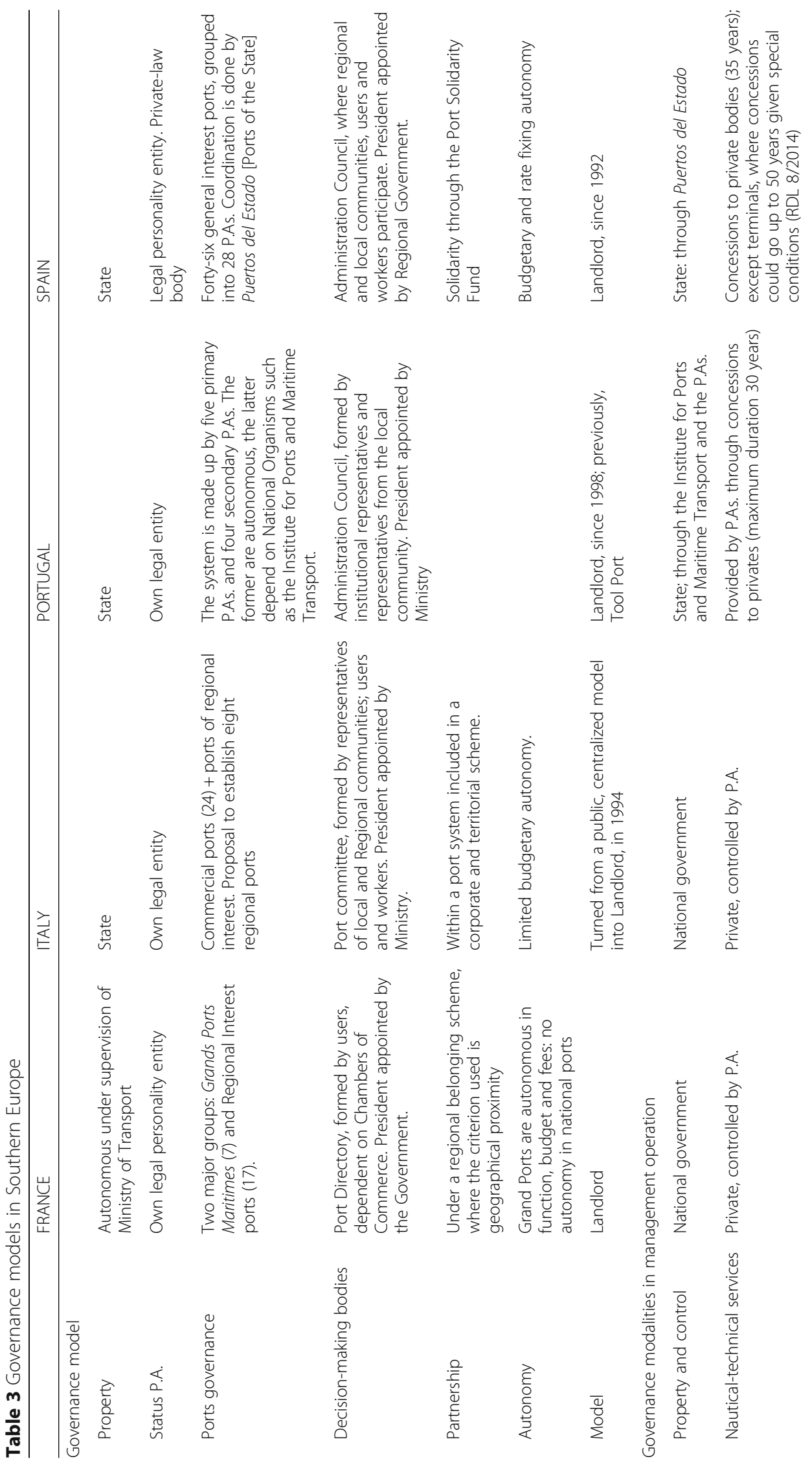




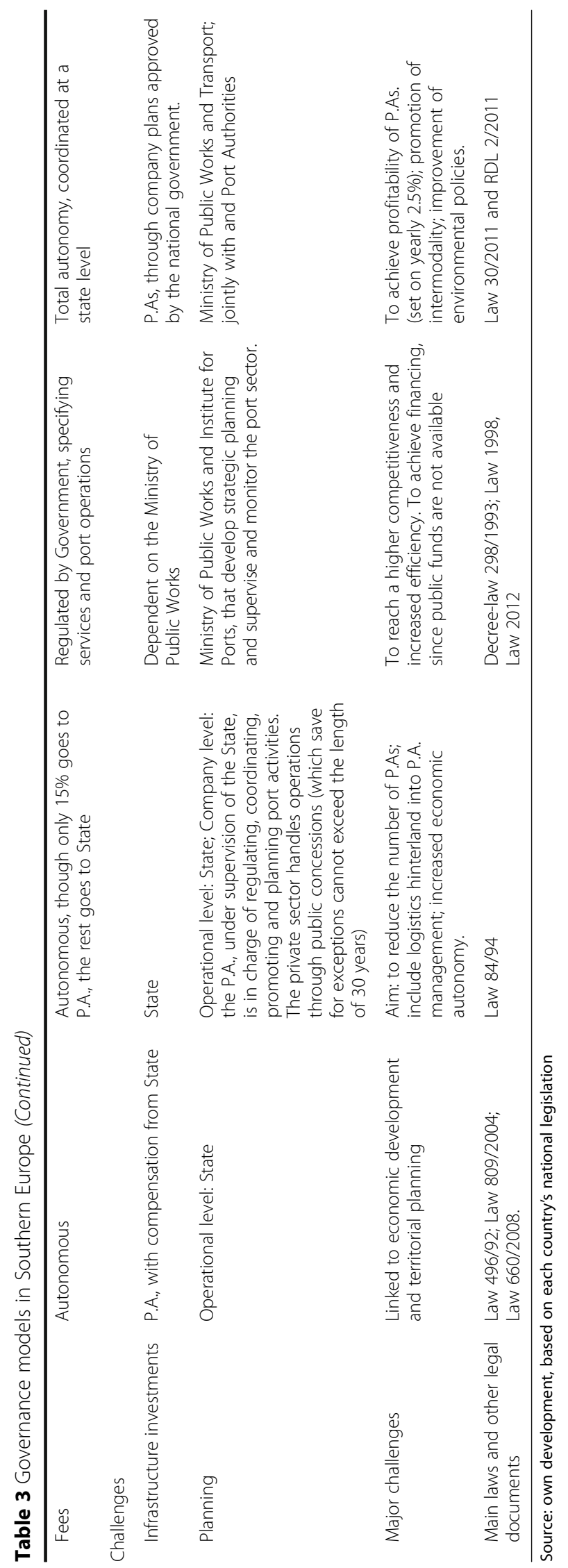


governance model. These are clearly related to the evolution of time and institutions rather than to a foundational situation, such as proposed by the original scheme that dates back 25 years. For example, this occurs when the decision is taken to move from straightforward port operation and regulatory action to public policy design and action focused on serving the common interests of society. This shift in the orientation of public policies, combined with technological change and the trade boost from globalization, creates a set of opportunities for change in processes and strategies that can lead to a programme of reforms and a shift to a new governance.

Indeed, Brooks and Cullinane begin by pointing out that the dynamics of port development themselves can yield new opportunities for improvement from the governments. It is important to stress, however, that other elements can also feed back into the process and once again can drive a programme of reforms leading for a new governance. These type of new elements are present in both Southern Europe and South America. Some of the main drivers are as follows:

- The interaction of ever-advancing trade and globalization with technological change, as this produces feedback that can push traditional ports to the edge of their expansion capacity.

- Partial attainment of the original objectives, which can prompt the consideration of what new goals might be needed, taking advantage of lessons learned and new instruments that were not part of the original design.

- Changes in the market (and in technology), lack or excess of competition and shifts in bargaining power between actors within the market that can result in monopsonies or oligopsonies (the original objectives included the prevention of monopolies but not of monopsonies).

As time passes, a governance model may be called into question because of its intrinsic characteristics or because of the results achieved, in the light of various considerations.

Having analysed the literature on the matter, and several experiences, it becomes evident that the concepts of governance and landlord require more debate in order to reach a more comprehensive definition and its implementation. The cases analysed in this paper, coinciding with a broad pre-existing literature, clearly show that despite the basic definitions of traditional governance models (service, tool, private and landlord), the different applications observed in each port (and within a country) hinder the unequivocal distinction of the application of each one in a "pure" manner.

"The most striking feature to emerge from our analysis of national situations is the persistence of a hybrid model which combines aspects of the market-based landlord port model with aspects of the more classical tool port model." (Debrie 2010, page 8). Consistently, when analysing governance models in 42 ports from 13 countries around the world, including 3 out of the 8 countries analysed in this paper, Brooks and Cullinane (2007) have identified the existence of multiple strategic objectives that can be managed and monitored in a wide variety of ways. It is worth noting that in the analysed sample, most case ports had been identified under a landlord model. Said study covered aspects such as the objectives behind governance models, ways to deliver services such as cargo-handling, chandlery, on-dock storage, container terminal operations, anchorage, 
port information, management of vessel traffic, container maintenance, towage, security, waste disposal, pilotage, customs and other administrative services, general marketing of the port, stevedoring labour hiring, and other governmental duties such as regulation, planning, and investment, among others. The authors concluded that the traditional port governance models identified by "Baird (2000) and the World Bank (undated) are oversimplified, cannot be validated, and do not reflect the hodgepodge of 'infinite variety' implemented in today's highly competitive port environment" (Brooks and Cullinane 2007, page 434).

Another view to be examined is the concept of governance that has often been restricted, at the legal and functional levels, to the inside of ports, and tied to regulations that were designed in times when port activities were much simpler (UNCTAD type). Meanwhile, a wider, comprehensive and unified logistics concept has replaced the older concept of services that are provided separately from the transport and distribution chain, thus imposing the necessity to grant efficiency and efficacy to the logistics chain as a whole (Sanchez and Pinto 2015).

The question now arises as to whether this governance still in place in each country, particularly in Latin America, is capable of assuming the challenge of influencing an extended logistics chain. Indeed, the changes that took place in Argentina and Brazil followed modifications in the original proposal, but not an adjustment to a shifting environment. In the case of Argentina, post-2012 modifications relate to the institutional organization and coordination at the State level, turning the sector into a web of disjointed organisms controlled by different Ministries. The first changes applied in 2016 have started to untangle the situation, a still ongoing process. As for Brazil, the situation is slightly different. The latest modifications sought to expand port infrastructure, modernize port administration, stimulate private investment and improve competitiveness, easing the way for new operators. To this end, the legislation puts an end to a longdated distinction between own cargo (which originally posed a limitation on TUPs ${ }^{8}$ ) and third-party cargo, as well as lifting the restrictions on the development of new terminals as long as they belong to the common area of the port. Despite these major changes, which still need to be revised, it should be noted that the reform intended only to solve a long-standing issue, but did not entirely address the new challenges of governance.

These circumstances pose an enormous challenge. As previously mentioned, Vanoutrive (2012) identifies three issues: i) the need for the governing entity to exert control over the governed entity, the latter of which now encompasses much more than just port facilities; ii) the lack of citizens over whom to exercise governance; and iii) the environmental impact. In addition to all of this comes institutional complexity, which deepens the diversity of models and the results of governance ( $\mathrm{Ng}$ and Pallis 2010).

The motivation in Latin America to apply reforms was common to almost every country: each country's search for an enhanced competitiveness in international markets, associated with the need for a better transportation network. The port system was in need of drastic changes, among which stood the need to reformulate roles and set clear rules for all parties involved. The aim was to facilitate the growth and competitiveness of economy and trade, by decentralizing, deregulating and privatizing, thus privileging economic efficiency. In the case of Southern Europe, although the concerns were similar, a reform in transport policies had already been set in motion. Consequently, as countries authorise new dispositions, the new role of the private initiative is 
progressively incorporated (today, private agents are already involved in decisionmaking together with Port Authorities.) Furthermore, the European Commission is currently including the private initiative in its resolutions, and proposes formulas of "public-private partnership" in order to assume investments in infrastructure and projects for new rail accesses into ports. Meanwhile, the consecutive dispositions approved by Southern European Countries have enjoyed widespread support from the sector; meaning, these decisions were adapted after a sustained joint initiative on the part of public and private agents.

All things considered, it is possible to say that ports in Southern European countries have plunged head into an adaptation of their port governance. In Latin America, however, recent changes denote a greater tendency to reinforce the bases of original reforms, taking the port environment as the sole core of governance (save for a slight exception in Peru). Twenty-five years later, Latin America is in need of a revision of its port governance, adopting a less sectoral and more comprehensive consideration of the chain.

Several of the original objectives of the reforms were fulfilled (at least partially), while others have emerged following the evolution of the markets. By consulting Fig. 1 it can be deduced that introducing a reform that adapts governance to the new context would be fitting. For instance, regarding the role of port authorities in Latin America, its approach is similar to that of Southern Europe countries, i.e. closer to the functions of a regulator and promoter. Even so, the reforms that took place over the past five years in Southern Europe have eased the insertion of the ports into the logistics chain, while in South America this remains a pending matter.

Generally speaking, Southern Europe has shown a higher capability of adaptation to change than Latin America, where it would be particularly convenient to embark on a revision of port governance through a more comprehensive and sustainable view.

\section{Conclusions}

Taking the literature into account, and in light of revised experiences, it is possible to suggest that port governance is the governance of the system of relationships and behaviours that define the functioning of a port in the context of a logistics chain. Port governance is an ensemble of mechanisms, processes and rules through which the authority over said activity is exercised, and refers to the behaviour of institutions being influenced by a varied set of agents and rules. In other words, governance may be seen as the decision-making process and the process through which such decisions are either implemented or not, being conditioned by the set of mechanisms, procedures and rules established by institutions, both formally and informally.

Considering the reviewed cases, it is possible to conclude that current port governance in Latin America is tied to the definition provided by UNCTAD in 1992; meanwhile countries in Southern Europe have begun to shift towards the role described by Drewe and Janssen (1996). In both cases, reforms have aided the modernization process of ports, the influx of private capital, the standardization of public-private association, the increase in productivity, and the adoption of technical standards of operation that allow for the delivery of more or less universal port services. However, aspects such as the relationship with the workforce, the establishment of decision-making mechanisms for investment and capacity expansion, or the type of port authority, are yet to be sorted out. The main conclusions resulting from the analysed cases are as follows: 
- As opposed to their European counterparts, traditional concepts of ports continue to form the basis of port governance in Latin America, and their adaptability to change has proved to be lower than in the case of Europe.

- There has been increased action in the European cases than in the Latin American cases to adapt ports (and, consequently, their governance) to the needs of an enhanced logistics chain.

- An unequal rhythm of port governance adaptation to contextual changes requires that the reform be considered an ongoing process.

- A profound revision of port governance would be advisable, particularly in South America, in order to adapt to changes and new challenges.

- It is essential to elaborate a common definition of port governance. It is also essential to develop further studies on the extent of the term 'landlord', taking into consideration how it is merely the initial definition of public property and private exploitation that are common to the analysed cases, while there exists a large variety in the remaining components of governance and the relationship between State and individuals in port activity.

The definition of 'landlord model' should indeed be re-examined, given the existence of as many landlord models as cases analysed. The subsequent discussion concerns the validity of the current landlord system and its capacity to adjust. Based on the cases analysed, it is possible to conclude that current port governance in Latin America is in need of a renewal, since the current base concepts are clearly related to old definitions (like UNCTAD in 1992) and not linked to a modern concept of the role of ports and the connection with the productive and logistics chains, both at the national and global level. A similar reconsideration would be advisable for port governance within the framework of an integral and sustainable policy. It is necessary to adopt a more comprehensive perspective of port development and operation, in order to enhance efficiency throughout the logistics chain, including both expanding investments and improving productivity and connectivity.

In summary, Southern Europe has shown a higher capability of adapting to change than Latin America. The analysed Southern European countries showed no concern regarding the contents of the definition of governance, taken as an academic or merely administrative concept. Thus, diverse port systems coexist, with organizational structures that differ in levels of participation as well as in regards to decision-making. Likewise, different financing models and services provision models coexist as well, as a consequence of dissimilar stakes on governance. However, a characteristic common to port systems in Southern Europe continues to be the acceptance of changes, that is, non-dependency on traditional institutional instances (path dependence). On the contrary, in the case of the Latin American countries analysed, it is possible to observe an adjustment to objectives previously set by public policies at the onset of the process (early 1990s), and a gradual lack of adaptation to changes that took place in the port environment. Ultimately, the fact that there is a difference between adaptation rhythms supports the idea that port governance is not a state as much as it is a dynamic process, in continuous evolution, intended to answer to the changing conditions of the environment.

The analysed reforms both in South America and Southern Europe are the result of decisions made by law-makers and government officials but also pressure by private 
companies. Both regions must improve their efficiency, take advantage of opportunities and achieve a better integration into global supply chains. To this end, it is vital to reach a thorough understanding of the forms that port governance takes, so it can be perfected with views on fulfilling the stated objectives.

Finally, some relevant aspects could not be considered in this paper, due to its qualitative nature. For instance, authors have recognized one of those being the relationship between the governance structure and the outcomes, in quantitative terms, the time lag between reforms and the effective change of port governance and the relationship between reforms, governance and institutions, among others. Those matters should form part of future research.

\section{Endnotes}

${ }^{1}$ Regarding Latin America, that evolution provided two different models of port governance: models 1.0 and 2.0 (see Sanchez and Pinto 2015.)

${ }^{2}$ For a deeper knowledge of the effect of the legal proposals in port governance, see (Pallis 2007).

${ }^{3}$ Certainly, there is a feedback between the governance model and its corresponding outcome.

${ }^{4}$ The variety of the actually existing port governance models surpasses the basic theoretical models.

${ }^{5}$ The collapse was due to a period of insufficient investment, and internal organization and market issues.

6"For many years, port deficits were considered of minimal importance and a matter that could be corrected with larger budget allocations or simply by raising charges. However, such increases for nations which have adopted export-oriented macroeconomic policies will ultimately affect the price of both exports and imports" (ECLAC 1992).

7"In the last decade of the twentieth century, governments face a fundamental choice: either they identify and define appropriate roles for the public and private sectors in ports vis-à-vis international trade or accept a reduction in the competitiveness of their exports in world markets, a contraction in foreign exchange receipts, a decline in domestic investments and a higher level of national unemployment" (ECLAC 1992).

${ }^{8}$ Private Use Terminals (from Portuguese Terminais de Uso Privado).

Acknowledgement

The authors would like to thank Eva Nicole Sánchez Salvá for her work on the translation of the article. Garcia-Alonso would also like to thank the Government of Spain for their contribution by means of the MTM2014-54199-P project. Finally, Ricardo Sánchez would also like to gratefully acknowledge the valuable comments of Octavio Doerr and Oscar Medina regarding the cases of Chili and Colombia.

Authors' contributions

All the authors have been involved in the whole paper. Additionally, each has been responsible of a particular section. Namely: FGL: Analysis of the process of port governance in the European countries. RJS: Analysis of the process of port governance in the Latin American countries. LG-A: Revision of the literature and corresponding author. All authors read and approved the final manuscript.

Competing interests

The authors have no competing interests that could influence the results and discussion reported in this paper.

${ }^{1}$ Dpto. Economía Aplicada I, Universidad de A Coruña, A Coruña, Spain. ²División de Recursos Naturales e Infraestructura, CEPAL, Naciones Unidas, New York City, NY, USA. ${ }^{3}$ Regional Economics Laboratory (REGIOlab). Applied Economics Department, University of Oviedo, Oviedo, Spain. 
Received: 2 March 2016 Accepted: 5 December 2016

\section{Published online: 20 December 2016}

\section{References}

Baird AJ (2000). Port privatisation: Objectives, extent, process and the U.K. experience. Int J Maritime Econ 2(3):177-194

Baltazar R, Brooks MR (2001) The Devolution of Port Management: A Tale of Two Countries, presented at the World Conference on Transport Research, Seoul, July

Baltazar R, Brooks MR (2007) Port governance, devolution and matching framework: a configuration theory approach. In: Devolution, port governance and port performance. Research in transportation economics, vol Chapter 17., pp 379-403

Borges Vieira GB et al (2014) Port governance model by Managers' and Customers' point of view: a study at port of Valencia, Spain. Int Bus Res 7(8):1-16

Brooks MR (2004) The governance structure of ports. Rev Netw Econ 3(2):168-183

Brooks MR, Cullinane K (2007) Governance models defined. In: Brooks MR, Cullinane K (eds) Research in transportation economics, vol 17. The Netherlands, Elsevier, pp 405-435

Brooks MR, Pallis AA (2008) Assessing port governance models: process and performance components. Marti Policy Manag 35(4):411-432

CEPAL (2015) Perfil marítimo y logístico de América Latina y el Caribe. Available at: http://www.cepal.org/perfil/. Accessed 2 Oct 2015

Cullinane K, Song D (2002) Port privatization policy and practice. Transp Rev 22(1):55-75

Debrie J, Lavaud-Letilleul V, Parola F (2013) Shaping port governance: the territorial trajectories of reform. J Transp Geogr 27:56-65

Debrie J (2010) Different tiers of government in port governance: some general remarks on the institutional geography of ports in Europe and Canada. World Conference on Transport Research Society, 12th World Conference on Transport Research, Lisbonne, p 16

De Langen (2007) Stakeholders, conflicting interests and governance in port clusters. In: Brooks MR, Cullinane K (eds) Devolution, port governance and port performance. Research in transportation economics, vol 17. The Netherlands, Elsevier, pp 457-476

Drewe P, Janssen B (1996). What ports for the future? From "main ports" to ports as nodes of logistics networks. European Regional Science Association. 36 th European Congress, ETH Zurich, Switzerland. 26-30 August 1996

Ferrari C, Parola F, Tei A (2015) Governance models and port concessions in Europe: commonalities, critical issues and policy perspectives. Transp Policy 41(0):60-67

Geiger A (2011) Modelo de governança para apoiar a inserção competitiva de arranjos produtivos locais em cadeias globais de valor. Phd Thesis. Universidade Federal do Rio Grande so Sul. Escola de Engenharia. Programa de Pós-Graduaçao em Engenharia de Produçap.

González Laxe F (2008) Gobernanza portuaria: principales trayectorias. Rev Econ Mundial 18:355-368

González-Laxe F (2013) Experiencias internacionales sobre el rol del estado para el desarrollo de sistemas portuarios en ambientes de competencias. Documento de trabajo de la División de Recursos Naturales e Infraestructura (DRNI) de CEPAL. Santiago, Chile

Lam JSL, Ng AKY, Fu X (2013) Stakeholder management for establishing sustainable regional port governance. Res Transp Bus Manag 8:30-38

Monios J (2015) Identifying governance relationships between intermodal terminals and logistics platforms. Transp Rev 35(6):767-791

Ng AKY, Pallis AA (2010) Port governance reforms in diversified institutional frameworks: generic solutions, implementation asymmetries. Environ Plan A 42(9):2147-2167

Notteboom T (2007) Concession agreements as port governance tools. In: Brooks MR, Cullinane K (eds) Devolution, port governance and port performance. Research in transportation economics, vol 17. The Netherlands, Elsevier, pp 437-455

Pallis AA (2007). EU Port Policy: Implications for Port Governance in Europe. In: Devolution, port governance and port performance. Research in Transportation Economics. vol 17. pp 479-495

Sanchez RJ, Pinto F (2015) El gran desafío para los puertos: la hora de pensar una nueva gobernanza portuaria ha llegado. Boletín FAL, Facilitación del transporte y el comercio en América Latina y el Caribe. CEPAL, Naciones Unidas. 337 (1)

Stoker G (1998). Governance as theory: Five propositions. Int Soc Sci J 50(155):17-28

Talley WK (2009) Port Economics. Routledge, Oxon

UNCTAD (1992) Development and improvement of ports: the principles of modern port management and organization. United Nations Conference on Trade and Development, Trade and Development Board, Committee on Shipping, Ad hoc Intergovernmental Group of Port Experts, Geneva

Vanoutrive T (2012) The changing spatiality of port governance: the case of Antwerp. 52th Conference of the European Regional Science Association. 21 to 25 August, Bratislava, Slovakia

Verhoeven P (2009) European ports policy: meeting contemporary governance challenges. Marit Policy Manag 36(1):79-101

Verhoeven P (2011) European Port Governance. Brussel

Verhoeven P, Vanoutrive T (2012) A quantitative analysis of European port governance. Mar Econ Logist 14(2):178-203

World Bank (2007) Port Reform Toolkit. Second Edition. Pub. The Interantional Bank for Reconstruction and

Development. Washington, DC 